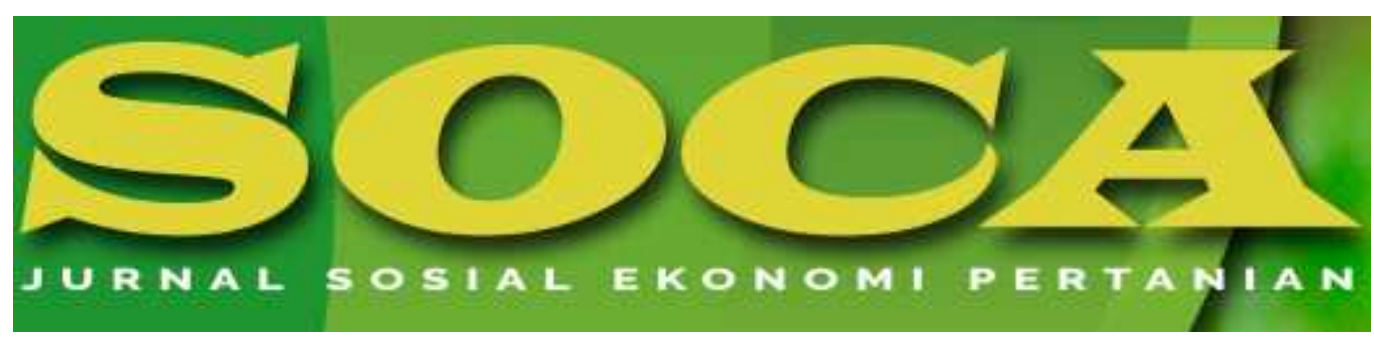

https://ojs.unud.ac.id/index.php/soca

\title{
NATION BRANDING KOPI ARABIKA KINTAMANI (Studi Kasus: Kopi Gunung Catur, Desa Catur, Kintamani, Bangli)
}

\author{
Ni Wayan Rainy Priadarsini Sukiada dan Anak Agung Ayu Intan Parameswari \\ Fakultas Ilmu Sosial dan Politik, Universitas Udayana, Denpasar, Bali \\ Email: rainypriadarsini@yahoo.com,parameswari.intan@gmail.com
}

Hp: 081337241748,081317158801

\begin{tabular}{l} 
Kata Kunci: \\
nation \\
branding, \\
pemerintah \\
Indonesia, \\
arabika \\
Kintamani, \\
Gunung Catur \\
\hline
\end{tabular}


terutama untuk kegiatan ekspor. Memasuki era industrialisasi 4.0, penguasaan Teknologi Informasi (TI) dan semangat kewirausahaan modern adalah strategi utama untuk mengembangkan kegiatan ekspor. Ini belum dikembangkan secara optimal oleh petani dan pengusaha kopi Gunung Catur. Maka melalui penelitian ini ditemukan bahwa penggunaan teknologi dan semangat kewirausahaan modern (technopreneurship) menjadi basis strategi komunikasi sebagai langkah strategis dalam meningkatkan peluang ekspor bagi produsen Kopi Gunung Catur.

\section{NATION BRANDING ARABIKA KINTAMANI COFFEE (Case Study: Gunung Catur Coffee, Catur Village, Kintamani, Bangli)}

\section{Keywords: nation branding, Indonesian Goverment, arabika Kintamani, Gunung Catur}

\begin{abstract}
Abstrak
Kopi Gunung Catur is a brand of specialty Arabica coffee that from Kintamani. This coffee brand has the export quality. This brand is cultivated by the farmer group named Subak Abian Tri Guna Karya. Today, branding has a significant role on the promotion in the international market. The Indonesian government began to build a nation brand for Indonesia Arabica coffee to avoid the claims from other countries and to expand market access. Likewise for Kopi Gunung Catur, there should be a proper strategy to improve the image of this coffee so its market access is increasingly wide open. Anholt said there are three strategies that can improve a country's product image, namely competence, contribution and communication. Kopi Gunung Catur that has been certified by Geographical Indications (IG) shows the ability of the farmers in Catur Village to cultivate coffee with good quality. Because it is cultivated organically, it enhances Indonesia's image worldwide about environmental protection. The philosophy Tri Hita Karana which is used as a cornerstone of its cultivation which synergizes human behavior and maintains the balance of nature strengthens the image of this coffee to the preservation of the nature. Kopi Gunung Catur has fulfilled the competency and contribution strategy. However, market access is still complained by Kopi Gunung Catur's farmers and coffee makers. Through the qualitative descriptive method, it is found that there is still only small effort to develop a third nation branding strategy, namely communication. The communication strategy contributes greatly in supporting the market access, especially for export activities. Entering the industrialization era 4.0, mastering Information Technology (IT) and having the spirit of modern entrepreneurship is the main strategy to develop export activities. This is not optimally boosted by farmers and entrepreneurs of kopi Gunung Catur. So through this research it was found that the use of technology and modern entrepreneurial spirit (technopreneurship) as the communication based strategy
\end{abstract}


became a right step in increasing export opportunities for

Kopi Gunung Catur producers.

How to Cite (APA 6th Style):

Sukiada, N. W. R. P., \& Parameswari, A. A. A. I. (2020). Nation Branding Kopi Arabika Kintamani (Studi Kasus: Kopi Gunung Catur, Desa Catur, Kintamani, Bangli). SOCA: Jurnal Sosial Ekonomi Pertanian, 14(1), 180-193.

https://doi.org/https://doi.org/10.24843/SOCA.2020.v14.i01.p15

\section{PENDAHULUAN}

Indonesia memiliki peluang ekspor kopi yang sangat besar. Pendapatan yang didapat Indonesia dari ekspor kopi tahun 2017 mencapai 469,4 juta dollar Amerika Serikat (AS). Jumlah ini menunjukkan peningkatan 10 persen dari tahun 2016 (Pitoko, 2019). Saat ini kopi sudah menjadi bagian dari gaya hidup masyarakat. Apalagi, terjadi peningkatan jumlah third wave coffee yaitu peminum kopi yang tertarik terhadap kopi, baik asal muasal bijinya, proses, penyajian hingga rasa kopinya. Di era ini pula muncul istilah single origin (wilayah asal kopi) (Yuliandri, 2015).

Pasar global saat ini menjanjikan untuk ekspor kopi Arabika. Hal ini membuat pemerintah Indonesia secara serius mendukung perkembangan kopi arabika. Saat ini kopi specialty Arabika diminati negara-negara yang memiliki penikmat kopi berkualitas tinggi. Ini menjadi peluang bagi Indonesia untuk dapat meningkatkan perekonomian nasional karena perkebuanan kopi tersebar dari Sabang hingga Merauke. Kopi Arabika Kintamani menjadi salah satu andalan specialty kopi bagi Indonesia. Salah satu tempat pembudidayaan dan pengolahan kopi arabika Kintamani dilakukan di Desa Catur, Kintamani, Kabupaten Bangli. Desa Catur, menghasilkan specialty kopi arabika yang berkualitas ekspor. Desa yang berada di di ketinggian 1.250 mdpl ini memiliki brand Kopi Gunung Catur yang memiliki kualitas ekspor. Kopi ini bahkan telah mendapat sertifikat kualitas kopi ASEAN (Den, 2019).

Dalam dua tahun terakhir telah terjadi penurunan harga kopi dunia yang merosot hingga 30 persen. Tahun 2019 harga kopi dunia berada di bawah US\$2 perkilogram (Andri, 2019). Harga kopi arabika Kintamani dari desa Catur pun ikut mengalami penurunan. Penurunan harga kopi mempengaruhi pendapatan petani kopi. Pendapatan yang timpang dengan biaya hidup membuat petani kopi arabika Kintamani mulai beralih ke tanaman lain yang lebih menguntungkan. Di Desa Catur Kintamani, jeruk menjadi pilihan lain untuk dibudidayakan karena hasilnya cukup menjanjikan. Hal ini berdampak pada penurunan luas perkebunan kopi, dan menjadi ancaman bagi ketersediaan pasokan kopi arabika Kintamani kedepannya. Petani dan pengolah kopi Arabika dari Desa Catur memerlukan bantuan pemerintah untuk dapat mempertahankan luas perkebunan kopi. Salah satu cara adalah menjaga harga komoditas kopi agar tetap stabil. Jika harganya stabil, petani bisa tetap membudidayakan kopi. Pemerintah tidak selalu dapat membeli seluruh kopi petani. Memperluas akses pemasaran dapat menjadi cara agar kopi para petani dapat terbeli. 
Upaya branding Kopi Arabika Kintamani perlu gencar dilakukan oleh pemerintah Indonesia. Hal ini menjadi serius mengingat persaingan pemasaran kopi arabika sangat ketat di pasar global. Berbagai negara yang terkenal dengan kopi arabikanya seperti Brazil, Vietnam, Jamaica, Ethiopia mengembangkan teknik pembudidayaan serta pengolahan kopi sesuai dengam standar internasional. Ini merupakan tantangan bagi Indonesia dalam upaya pemasaran brand kopi Arabika Kintamani.

Mempertahankan rasa kopi yang berkualitas menjadi hal yang wajib dilakukan petani kopi, namun upaya branding juga menjadi hal yang penting karena branding menjadi jalan bagi produk kopi arabika Kintamani Gunung Catur untuk memperluas area pemasarannya hingga ke kancah global. Peran negara menjadi signifikan dalam upaya branding produk kopi arabika Kintamani. Negara memiliki power untuk memasuki jaringan pasar yang lebih luas di berbagai belahan dunia. Negara juga memiliki kekuatan untuk melakukan tawar menawar, kegiatan diplomasi dan negosiasi dengan negara-negara tujuan ekspor kopi. Dalam Organisasi Kopi Dunia atau International Coffee Organisation (ICO) yang menjadi pusat pengelolaan perdagangan kopi internasional, peran negara sangat besar. Misalnya saja dalam hal perundingan, pembuatan kebijakan serta pemberian keputusan ekonomi terkait perdagangan kopi. Sehingga menjadi signifikan untuk melihat strategi negara dalam nation branding kopi arabika dari Indonesia.

Simon Anholt (1998) dalam Ostapenko (2010) menyebutkan bahwa suatu tempat atau negara bisa menjadi sebuah merek (Lestari, 2018). Strategi nation branding menjadi upaya dalam mempromosikan citra bangsa yang positif, membangun identitas merek bagi negara, memberi peluang dalam meningkatkan ekspor produk, serta investasi asing langsung (Anholt, 2003). Ada 3 strategi yang dapat meningkatkan nation branding yaitu kompetensi, kontribusi, dan komunikasi. Kompetensi berkaitan dengan kualitas yang dimiliki suatu negara untuk bersaing. Berikutnya, kontribusi merupakan hal-hal yang berhubungan dengan partisipasi, sumbangan, dan karya Indonesia pada konsumen global yang memiliki kaitan dengan kebudayaan masyarakat, pengembangan ilmu pengetahuan, tindakan perlindungan terhadap lingkungan dan upaya untuk mewujudkan kesejahteraan. Yang ketiga, komunikasi yaitu cara untuk menyampaikan pesan kepada khalayak mengenai kompetensi dan kontribusi suatu negara baik di tingkat lokal maupun internasional (Kurniawan, 2017). Ketiga strategi ini akan dibahas terkait nation branding kopi Gunung Catur oleh pemerintah Indonesia.

\section{METODE PENELITIAN}

Penelitian ini menggunakan metode deskriptif kualitatif, dengan memanfaatkan dua jenis data, yaitu data primer dan data sekunder. Data primer dalam tulisan ini diperoleh melalui wawancara mendalam. Bahan data primer diperoleh dari wawancara dengan pihak-pihak yang terkait dengan pihak pemerintah yaitu Dinas Tanaman Pangan, Hortikultura dan Perkebunan Provinsi Bali, Dinas Pertanian, Ketahanan Pangan dan Perikanan Kabupaten Bangli, Dinas Perindustrian dan Perdagangan (Disperindag) Provinsi Bali, Dinas Perindustrian dan Perdagangan Kabupaten Bangli, dan komunitas petani kopi Desa Catur Kintamani. Data sekunder didapat melalui dokumen-dokumen yang diperoleh pada Dinas Tanaman Pangan, Hortikultura dan Perkebunan Provinsi Bali, Disperindag Provinsi 
Bali, jurnal-jurnal dan buku yang membahas mengenai nation branding, produksi kopi nasional, pemberitaan media terkait topik penelitian serta data lain yang relevan dengan tema penelitian.

\section{PEMBAHASAN}

\section{Kopi Gunung Catur Sebagai Produk Kopi Specialty Arabika kintamani}

Pusat pembudidayaan dan kegiatan produksi kopi specialty arabika terluas di Bali ada di Kecamatan Kintamani (Priantara dkk, 2016). Sertifikat Indikasi Geografis (IG) telah diberikan kepada kopi ini sejak tahun 2008. Sertifikat IG memiliki arti penting bagi perlindungan hukum terhadap nama geografis asal produk, mengetahui keaslian asal produk dan dapat menjadi jalan bagi peningkatan pendapatan produsen (Kementan, 2017). Saat ini Perlindungan Hak Kekayaan Intelektual menjadi isu global. Berbagai negara di dunia telah mengalami banyak kasus terkait hal tersebut. Perlindungan Hak Kekayaan Intelektual menjadi langkah penting bagi produk unggulan suatu bangsa agar tidak diakui atau dapat dengan mudah digunakan negara lain untuk mencari keuntungan ekonomi (Alfons, 2017). Di Indonesia, wujud nyata dari penerapan ratifikasi Trade Related Aspect on Intelektual Property Rights (TRIPs) atau hukum internasional terhadap perlindungan kekayaan intelektual dilaksanakan melalui pembuatan UU tahun 2001 tentang merek dagang dan Perlindungan Indikasi Geografis dalam bab 56. Kemudian untuk pelaksanaannya diwujudkan melalui Peraturan Pemerintah No.51 Tahun 2007 tentang Indikasi-Geografis.

Masyarakat Perlindungan Indikasi Geografis (MPIG) menjadi hal yang khas dari pengelolaan dan pembudidayaan kopi arabika Kintamani. Kopi Gunung Catur dibudidayakan oleh Subak Abian Tri Guna Karya. Organisasi ini memiliki tujuan agar dapat membantu petani mengatasi permasalahan sosial, dapat melakukan pengelolaan dan pemasaran produk Kopi Arabika Kintamani dengan baik.

Kopi Kintamani Bali layak mendapat sebutan origin coffee atau kopi asli Indonesia karena memiliki sistem pertanian yang kental dengan unsur-unsur kebudayaan Bali yaitu subak yang memiliki aturan adat atau awig-awig yang mengatur kegiatan para anggota petani kopi. Pembudidayaan kopi arabika Kintamani dilakukan secara organik yang menggunakan pupuk kandang untuk membantu menyuburkan tanamanan dan ditanam di sela-sela tanaman penaung yaitu jeruk, cengkeh dan kakao. Hal ini dikatakan petani kopi dapat membantu memberikan untuk cita rasa unik kopi arabika Kintamani yang berasa citrus. Luas perkebunan kopi di Desa Catur saat ini mencapai 560 hektar dengan luas kebun yang dimiliki petani berbeda-beda satu dengan yang lainnya.

Kopi Gunung Catur adalah salah satu contoh merek kopi hasil pengolahan kopi yang ada di Desa Catur. isPpenggunaan sitem pertanian yang berkelanjutan serta menggunakan filosofi Tri Hita Karana menjadi konsep pembudidayaan kopi ini. Pemberdayaan masyarakat lokal dilakukan dengan melatih masyarakat dari Desa Catur untuk memelihara pohon-pohon kopinya agar memiliki buah yang berkualitas. Kualitas kopinya dijaga agar menghasilkan kopi yang bermutu tinggi. Semua hal ini dilakukan dan mendapat pengawasan dari pengusaha dan petani kopi yang berdedikasi yaitu Bapak Ketut Jati.

Pada tahun 2019 Panen Raya Kopi Arabika Kintamani dilakukan pada bulan Juli. Hasil dari panen raya kopi arabika tersebut mengalami peningkatan 10 ton dari 
tahun sebelumnya. Tahun 2019 panen kopi arabika Desa Catur mencapai 40 ton. Kopi yang dipetik adalah kopi gelondong merah dengan kualitas baik. Panen ini dilakukan oleh kelompok petani kopi Subak Abian Tri Guna Karya yang saat ini diketuai oleh I Ketut Mulih. Selain itu perwakilan Badan Usaha Milik Negara (BUMN) seperti PT Asuransi Jasa Indonesia Persero (Jasindo) dan PNM (Penanaman Modal Madani) juga ikut serta dalam kegiatan panen ini. Kedua BUMN ini menjalin kerjasama dalam membantu petani kopi meningkatkan semangat pembudidayaan kopi. Bantuan permodalan yang diberikan oleh kedua lembaga ini mencapai 1 milyar rupiah kepada tahun 2018. Hal ini menurut Ketut Jati sangat membantu petani kopi untuk tetap berfokus dalam membudidayakan kopi arabika Kintamani.

Dalam sebuah wawancara dengan pak Ketut Jati, dikatakan bahwa Kopi arabika Gunung Catur telah diekspor oleh pihak ketiga ke Jepang, Korea Selatan dan Taiwan. Hal ini menunjukkan bahwa kualitas kopi Gunung Catur telah diakui di pasaran internasional. Jepang menjadi salah satu negara peminat kopi arabika dari Indonesia. Jepang menjadi pasar yang potensial untuk kopi arabika dari Indonesia karena karena budaya minum kopi di negara inimengalami peningkatan yang signifikan belakangan ini. Data Disperindag Provinsi Bali menunjukkan adanya peningkatan ekspor kopi ke Jepang dengan jumlah total ekspor mencapai $1.273 \mathrm{~kg}$ pada bulan Januari-Juli 2019. Jumlah ini mengalami peningkatan yang drastis jika dibandingkan ekspor kopi dari Bali ke Jepang tahun 2018 yang hanya mencapai 154 kg. Selain Jepang, Taiwan dan Korea Selatan juga menjadi pasar baru yang dapat membantu peningkatan untuk ekspor kopi arabika Kintamani. Ekspor kopi dari Bali ke Taiwan bahkan mencapai $17.935 \mathrm{~kg}$ (Kristianto, 2019). Hal ini terjadi karena mulai banyak bermunculan kedai ataupun gerai-gerai kopi serta gaya hidup anak muda Taiwan yang lekat dengan kopi.

Citra Bali sebagai destinasi pariwisata dunia memberi menilai tambah dan persepsi positif masyarakat internasional terhadap produk dari Bali (Sri dan Reni, 2014). Hal ini juga berdampak pada kopi arabika Kintamani. Peningkatan wisatawan Jepang yang masuk ke Indonesia sangat besar pada tahun 2019 dengan kunjungan wisatawan Jepang ke Bali mencapai 33.474 orang menduduki peringat ketiga tertinggi (Projo, 2019). Hal ini menjadikan produk dari Bali lebih mudah dikenal oleh masyarakat Jepang, termasuk juga Kopi Arabika Kintamani.

\section{Tantangan Dalam Pemasaran Kopi Gunung Catur ke Pasar Internasional}

Pak Ketut Jati dan beberapa petani kopi yang secara bersamaan diwawancara mengatakan bahwa Kopi Gunung Catur memiliki kualitas ekspor dengan ciri-ciri bentuknya bagus, tidak ada cacat dan tidak ada jamur. Namun jika melihat harga kopi dunia, harga kopinya jauh dibawah harga kopi specialty arabika Kintamani, sehingga harus dicari pasar yang sesuai dengan biaya produksi kopi ini. Menurut Bapak Ketut Jati, kegiatan yang lebih banyak dilakukan petani dan pengolah kopi adalah kegiatan fisik, namun untuk kegiatan pemasaran bahkan ekspor lebih banyak diserahkan kepada pihak ketiga baik eksportir ataupun pemerintah. Petani ataupun pengolah Kopi Gunung Catur belum dapat langsung bertindak sebagai eksportir. Pendapatan yang didapatkan petani dan pengolah hanya hasil tenaga mereka bukan kegiatan negosiasi maupun tawar menawar dengan buyers dari luar negeri. 
Harga perkilogram kopi Gunung Catur yang diproduksi hanya Rp.100.000,-, jika dibandingkan harga kopi percangkir yang jika masuk café atau coffee shop harganya secangkirnya berkali-kali lipat lebih mahal. Tentu terdapat perbedaan keuntungan yang sangat timpang antara petani kopi dan pengusaha coffee shop. Pak Ketut Jati mengungkapkan "tiyang nak belog, yan ngae seduhan kopi tiyang bisa, pang nyak anake meblanje, pemasaran, periklanan yang butuh dana banyak dan strategi, belum mampu". Umumnya petani disini belum memperoleh pendidikan yang merata hingga ke jenjang perguruan tinggi. Hal ini menyebabkan lemahnya kemampuan mereka untuk mengakses informasi yang berkaitan dengan pasar kopi internasional, jaringan dan selera konsumen internasional, dan pola pemasaran kopi global. Kopi arabika Kintamani memang sudah masuk ke berbagai pasar internasional, namun pemasarannya banyak dilakukan oleh pihak ketiga atau jasa perantara misalnya eksportir dari Surabaya.

Masih terbatasnya mesin pengolahan kopi menjadikan produksi kopi arabika tidak bisa sebanyak dan secepat yang diinginkan pasar. Para eksportir terkadang harus mencari kopi arabika dari daerah lain di Indonesia kemudian semua kopi arabika tersebut digabungkan sehingga jumlahnya mencukupi permintaan pasar internasional. Kecenderungan untuk pergantian merek kopi dalam hal ini sangat mungkin terjadi karena proses penggabungan kopi-kopi arabika ini. Padahal jika petani kopi memiliki akses langsung pada buyers di luar negeri maka proses distribusi dan pemasaran serta ciri khas kopi masing-masing tidak akan hilang.

Kurangnya pengenalan branding produk Kopi Arabika Gunung Catur juga disebabkan oleh rendahnya penguasaan teknologi oleh pelaku usaha. Inovasi teknologi terutama dalam penggunaan TI masih dalam bentuk pengenalan produk, pengenalan wilayah ataupun untuk kegiatan pameran. Padahal TI dapat digunakan dengan lebih serius untuk peningkatan mutu dan diversifikasi produk, membantu peningkatan omset usaha serta pencarian pasar hingga ke luar negeri (Mopangga, 2015). Syarat dalam memasuki era industrialisasi 4.0 adalah pemanfaatan TI. Partisipasi anak muda lokal desa Catur dalam penguasaan TI serta menumbuhkan jiwa kewirausahaan modern perlu didorong secara konsisten. Istilah kerennya adalah technopreneurship. Technopreneur merupakan penggabungan teknologi dengan pasar. Technopreneurship seharusnya dapat menjadi strategi komunikasi dalam nation branding memecahkan kesulitan pasar yang dihadapi oleh produsen kopi arabika Gunung Catur.

\section{Upaya Nation Branding Pemerintah Untuk Kopi Arabika Kintamani}

Saat ini sektor yang tumbuh pesat dari industri kopi adalah gerai ataupun kedai kopi. Tahun 2019 terdapat dua gerai kopi yang mengusung kopi Indonesia yaitu Fore Coffee berhasil mendapat suntikan dana dari investor mencapai 127 miliar rupiah, sedangkan Kopi Kenangan mendapat dana investor sebesar 282 miliar rupiah. Hal ini terjadi karena kedua gerai tersebut mengimplementasikan technopreneur dengan mengandalkan pemasaran menggunakan teknologi. Bahkan sebagian dari dana investasinya tersebut digunakan dalam pengembangan teknologi aplikasi yang memudahkan konsumen untuk memesan minuman kopi (Sari, 2019).

Hal ini berbanding terbalik dengan hilirisasi industri kopi yang masih mengalami banyak permasalahan. Kendala yang dihadapi tidak hanya dari sisi produksi, manajemen keuangan, pembiayaan bahkan hingga akses pemasaran. 
Padahal proses ini mempengaruhi kesejahteraan petani dan usaha pengolahan kopi. Kesejahteraan petani kopi meningkat jika produk kopinya dibeli dengan harga yang bagus. Secara nasional stok kopi arabika Kintamani selalu kekurangan, sehingga jumlah kopi yang dikirim ke pihak eksportir harus dibagi-bagi. Seperti yang diungkapkan Kepala Bidang Perkebunan, Dinas Tanaman Pangan, Hortikultura dan Perkebunan Provinsi Bali, Lanang Aryawan "eksportir seperti Indocom dari Surabaya meminta sekian ton kopi Arabika Kintamani, namun eksportir kopi arabika lainnya juga meminta sekian ton kopi arabika Kintamani, sehingga pasokannya harus kami bagi ke eksportir-eksportir secara merata".

Ketika kopi arabika Kintamani banyak dicari oleh penikmat kopi lokal maupun dari luar negeri, maka harga kopi seharusnya bisa melambung tinggi. Namun hal ini tidak terjadi pada petani kopi arabika Kintamani. Petani kopi arabika Kintamani merasakan fluktuasi harga kopi dari tahun ke tahun. Pada tahun 2013 harga kopi sempat anjlok tajam. Memang sampai saat ini nasib petani masih ditentukan oleh pihak-pihak tertentu yang selalu bisa mengontrol pergerakan harga, sehingga petani yang merasakan dampak paling besar ketika harga kopi merosot tajam. Pendapatan petani tergantung pada harga hasil panen, mereka menginginkan harga lebih tinggi dari biaya-biaya yang telah mereka habiskan untuk pemeliharaan buah kopi. Namun pihak pengolahan kopi berkeinginan sebaliknya, agar harga kopi dari petani jangan sampai lebih tinggi dari biaya yang dikeluarkan oleh pengolah kopi. Karena biaya untuk pengolahan kopi juga besar.

Negara perlu memberi solusi bagi permasalahan para petani dan pengolah kopi arabika Kintamani, sehingga produksi kopi arabika Kintamani semakin meningkat dan penurunan jumlah lahan kopi dapat ditekan seminimal mungkin. Negara memiliki strategi dalam menangani permasalahan produk dalam negerinya melalui kegiatan ekspor. Peluang ekspor dapat diperbesar jika negara menciptakan persepsi positif masyarakat internasional terhadapnya (Anholt, 2010). Dalam hal ini, branding digunakan untuk meningkatkan status negara melalui identitas yang unik serta upaya untuk menyampaikan kesan tersebut pada negara-negara lainnya. Jika negara mendapat kesan yang positif dari negara lain, maka akses akan semakin terbuka lebar.

Ekspor menjadi aspek penting dalam nation branding. Kegiatan ekspor memerlukan akses pasar yang luas serta kebijakan-kebijakan yang mendukung inovasi serta koordinasi yang baik bagi berbagai pihak yang berkepentingan. Nation branding memiliki fungsi membangun, mengembangkan dan mempertahankan pencitraan (reputasi) yang positif bagi suatu negara (Prasetya, 2015). Seperti pernyataan Anholt, bahwa reputasi suatu negara diperoleh melalui kompetensi dan kontribusinya terhadap dunia internasional. Sedangkan faktor komunikasi menjadi sarana penting untuk mengirim pesan ke berbagai negara. Mentransfer image positif melalui proses komunikasi menjadi muara dari kompetensi dan kontribusi suatu negara dalam kacah global. Komunikasi menjadi kunci dalam meningkatkan popularitas dan peluang perluasan pasar untuk produk yang dihasilkan.

Contoh negara yang berhasil mengelola dan menjual nation branding-nya adalah Korea Selatan. Korean wave menjadi bentuk kebudayaan popular negara tersebut yang diperkenalkan ke berbagai belahan dunia melalui musik, film, hingga drama televisi. Kekuatan utama dari Korean wave adalah perpaduan unsur tradisional dan modern dari budaya Korea Selatan. Pemerintah Korea Selatan 
mendukung secara maksimal Korean wave melalui kebijakan, penelitian, pendidikan dan pelatihan masyarakatnya secara profesional. Kemudian dibantu dengan pendanaan yang maksimal Korean wave dikomunikasikan dan disebarkan ke penjuru dunia. Bersamaan dengan itu, pemerintah Korea Selatan medorong produk-produk komersial yang dihasilkan oleh Korea Selatan untuk ikut dipasarkan, misalnya saja produk teknologi seperti Samsung, LG, ataupun produk otomotif seperti KIA dan lain-lain. Masyarakat internasional yang telah mengenal Korean wave dengan baik dapat menerima bahkan menjadi fanatik terhadap produk-produk yang dihasilkan oleh Korea Selatan. Hal inilah yang menjadikan nation branding Korea Selatan berhasil dalam mendukung peningkatan perekonomian negara tersebut.

Bentuk komunikasi Indonesia dalam membangun nation branding saat ini terkesan masih terkotak-kotak, misalnya saja dari sektor perdagangan yang menggunakan brand "Remarkable Indonesia" sedangkan sektor pariwisata menggunakan brand "Wonderful Indonesia" (Sudarwati, 2016). Hal ini dapat memperlemah upaya nation branding Indonesia. Berkaca upaya Korea Selatan yang telah menemukan strategi yang tepat dalam menggambarkan keunikan negaranya, ditambah dukungan yang maksimal dari pemerintah dalam proses promosi ke luar negeri menunjukkan ddilaksanakannya strategi nation branding yang ketiga yaitu komunikasi. Sehingga Korea Selatan telah menjalankan ketiga nation branding strategi yang dipaparkan Anholt yaitu kompetensi, kontribusi dan komunikasi melalui Korean wave.

Kementerian Luar Negeri melalui Direktorat Diplomasi Publik menampilkan Indonesia yang moderat, demokratis dan progresif sebagai bentuk komunikasi nation branding kepada masyarakat internasional (Sudarwati, 2016). Namun hal ini belum mampu menandingi nation branding seperti Korea Selatan dan Malaysia. Masih diperlukannya penggalian konsep yang tepat yang dapat digunakan oleh seluruh pihak dan koordinasi yang baik antar kementerian dalam kegiatan promosi dan pameran keluar negeri untuk dapat menunjang proses nation branding Indonesia.

Country of Origin (COO) berhubungan dengan merek suatu produk yang didalamnya terdapat letak geografis, kondisi ekonomi, politik, sosial dan budaya masyarakat. Sehingga jika dihubungkan dengan COO maka konsumen yang mencari kopi Arabika Gunung Catur akan mengkaitkan produk tersebut dengan tempat asal (daerah maupun negara) dan segala atribut yang melekat pada produk tersebut. Sertifikat IG menjadi brand kopi arabika Gunung Catur yang mampu meningkatkan daya tawar yang lebih tinggi untuk produk ini. Pak Ketut Jati yang diwawancara menyebutkan bahwa sertifikat IG memang berdampak pada peningkatan harga kopi arabika Kintamani. Kopi arabika Kintamani yang saat ini telah besertifikat IG untuk green bean harga mencapai Rp.100.000 perkilogram, sedangkan jika dalam bentuk sangrai harganya Rp.200.000 perkilogram. Jika dibandingkan dengan kopi biasa atau yang tidak bersertifikat IG dalam bentuk green bean rata-rata hanya Rp.27.000 perkilogram sedangkan dalam bentuk sangrai harganya Rp.60.000 perkilogram. Perbandingan harga tersebut menunjukkan bahwa kopi yang memiliki sertifikat IG harganya jauh lebih tinggi sehingga membuat petani kopi termotivasi untuk membudidayakannya. Walaupun begitu, harga kopi arabika Kintamani masih saja berfluktuasi tiap tahun. Hal ini disebabkan harga 
kopi Arabika Kintamani masih dipengaruhi harga kopi dunia. Harga kopi secara global dikendalikan oleh bursa berjangka dari negara lain yang justru tidak menjadi produsen kopi. Sehingga pemerintah perlu mendorong Bursa Berjangka Indonesia seperti Bursa Berjangka Jakarta (BBJ) dan Bursa Komoditi dan Derivatif Indonesia (BKDI) untuk dapat membentuk dan menentukan harga komoditas kopi.

Fluktuasi harga kopi arabika desa Catur Kintamani juga dipengaruhi oleh kelemahan yang dimiliki oleh kelompok MPIG. Idealnya MPIG yang melibatkan organisasi petani, instansi pembina dan mitra (buyers) diharapkan dapat meningkatkan kualitas kopi serta kesejahteraan petani kopi. Belum maksimalnya kesadaran petani kopi untuk memanfaatkan koperasi MPIG karena masih ada petani-petani yang menjual biji kopinya sendiri-sendiri. Hal ini menyebabkann koperasi ini tidak berkembang pesat. Unit Pengolahan hasil (UPH) yang dulunya berjumlah 33 sangat ini turun hanya menjadi 10 (Ardana, 2017). Penyebabnya adalah kurangnya modal yang dimiliki koperasi untuk membeli hasil panen anggota. Dukungan pemerintah untuk meningkatkan kapasitas SDM dalam pengelolaan MPIG, penambahan infrastruktur, serta dorongan kepada para petani kopi untuk memanfaatkan koperasi sangat diharapkan oleh Pak Ketut Jati.

Dalam mempromosikan dan memasarkan kopi Indonesia, para produsen dan eksportir kopi masih menggunakan nama daerah tempat kopi berasal pada kemasan masing-masing, misalnya kopi Sumatra, Kopi Bali, Kopi Jawa dan lain-lain. Akibatnya para penikmat kopi cenderung lebih mengenal nama daerah penghasilnya dibandingkan dengan nama negaranya yaitu Indonesia. Hal ini kadang dapat membuat importir kebingungan karena pihak importer lebih mengenal nama negara dibandingkan namma daerah penghasil kopi. Sehingga Badan Ekonomi Kreatif (Bekraf) dan Speciality Coffee Association of Indonesia (SCAI) memutuskaan untuk meluncurkan logo "Kopi Indonesia" yang diharapkan dapat menjadi generic branding bagi kopi-kopi yang dimiliki oleh Indonesia. Logo ini sebenarnya tidak menghilangkan nama daerah asal kopi 1 karena dalam desainnya nama daerah tetap bisa dicantumkan (Highlish Media, 2019). Tujuan branding logo "Kopi Indonesia" kedepannya diharapkan dapat memperkuat jati diri dari bangsa Indonesia di ranah internasional dengan kopi-kopi yang berkualitas tinggi.

Sosialisasi penggunaan logo "Kopi Indonesia" menjadi penting untuk dilakukan. Hal ini dapat mencegah klaim dari negara lain. Ketika nama negara digunakan dalam merek kopi, maka ciri khas identitas suatu bangsa dan kekuatan politik dalam memasarkan kopi Indonesia di kancah internasional semakin besar. Berkaca pada kasus klaim kopi dari Indonesia pernah terjadi pada kopi Toraja yang pernah dimasukkan dalam label Key Coffee (perusahaan milik Jepang). Hal ini berdampak pada para eksportir kopi dari Indonesia. Mereka tidak bisa langsung menjual kopi ini di Jepang kecuali melalui Key Coffee. Jika eksportir mengekspor langsung ke Jepang, maka mereka akan dituding melanggar merek Key Coffee yang telah mendaftarkan kopi Toraja terlebih dahulu di Jepang sebagai kopi miliknya. Akibatnya ekspor langsung dari Indonesia tersendat karena harus melalui Key Coffee. Volume dan harga kopi Toraja yang masuk ke Jepang diatur oleh Key Coffee, hal ini berdampak pada rendahnya keuntungan yang didapat oleh eksportir Indonesia karena harus dibagi dengan Key Coffee (Devi, 2004). Hal ini juga berdampak pada penurunan devisa negara. 
Kopi arabika Kintamani Gunung Catur belum menggunakan logo "Kopi Indonesia", dan hal yang sama juga terjadi pada kopi dari wilayah lain di Indonesia. Pak Ketut Jati mengatakan telah ada sosialisasi dari Bekraf tentang kemasan dan merek untuk produk kopi namun dalam penggunaannya menjadi pilihan masingmasing. Mendorong kesadaran para petani dan pengolah kopi seperti Pak Ketut Jati mengenai pentingnya penggunaan brand Kopi Indonesia perlu dijalankan secara konsisten, sehingga potensi klaim produk Indonesia oleh negara lain dapat diminimalisir.

Jika dilihat dari peraturan ekspor kopi saat ini ternyata sudah lebih memudahkan petani, pengusaha ataupun perusahaan kopi di Indonesia untuk melakukan ekspor. Peraturan terbaru tentang ekspor yaitu Peraturan Menteri Perdagangan (Permendag) Republik Indonesia (RI) No.109 Tahun 2018 yang memuat ketentuan ekspor kopi yang merupakan perbaikan dari Permendag RI No.10 Tahun 2011. Berdasarkan wawancara dengan Staf Seksi Fasilitasi Ekspor Impor Disperindag Provinsi Bali, I Gde Bayu Kamayana menyebutkan bahwa ada beberapa poin dalam Permendag RI No.109 Tahun 2018 yang dapat mempermudah syarat pengekspor kopi. Saat ini untuk terdaftar sebagai Eksportir Terdaftar (ET) harus melengkapi dokumen-dokumen: (1) memiliki akta pendirian perusahaan, namun bukan perusahaan perseorangan, (2) memiliki surat rekomendasi dari Disperindag Provinsi, (3) perusahaan harus melampirkan surat permohonan kepada Disperindag Provinsi, fotocopi legalitas perusahaan, fotocopi Surat Ijin Usaha Perusahaan (SIUP), Nomor Pokok Wajib Pajak (NPWP), Nomor Induk Berusaha (NIB) dari Dinas Perijinan untuk ekspordapat mendaftar melalui Layanan Perijinan di bidang perdagangan secara elektronik (INATRADE).

Pada peraturaan ekspor yang lama, harus ada dua dokumen sebagai syarat multak eksportir yaitu Eksportir Kopi Sementara (EKS) dan Eksportir Kopi Terdaftar (ETK) yang setelah tahun 2018 dipangkas hanya menjadi ET. Peraturan sebelumnya juga menyebutkan EKS hanya bersifat sementara yaitu 1 tahun dan dapat diperpanjang. Aturan tersebut dapat ditingkatkan menjadi ETK jika telah melakukan ekspor sekurangnya 200 ton dalam 1 tahun. Hal ini menjadi hambatan bagi pengusaha kecil untuk melakukan ekspor. Namun pada peraturan yang baru hal ini sudah tidak diberlakukan lagi. Sehingga perubahan aturan ini diharapkan dapat meningkatkan kinerja Usaha Menengah Kecil (UKM). Peraturan yang lama membuat UMKM hanya undername dan harus menyalurkan ke perusahaan terlebih. Hal ini terjadi karena jumlah kopi yang dihasilkan harus besar jika ingin menjadi eksportir. Tetapi dalam peraturan yang yang baru bahkan petani kopi pun bisa langsung melakukan ekspor dengan berapapun jumlah kopi yang mereka punya. Tentunya harus tetap mengikuti standar kualitas yang diinginkan oleh buyers. Menurut Bayu perubahan ke peraturan yang lama ke peraturan yang baru ini dapat meningkatkan semangat UMKM untuk ekspor.

Kemendag RI melalui Direktorat Jenderal Pengembangan Ekspor Nasional (DJPEN) menjadi jendela Indonesia terkait dengan pengembangan ekspor. DJPEN melakukan identifikasi pasar dan dan melihat peluang baru di luar negeri bagi calon atupun para eksportir kopi. DJPEN memberi informasi tentang akses negara tujuan tradisional maupun ceruk pasar baru. Ekspor kopi saat ini banyak meningkat ke Cina, karena pergeseran pergaulan anak muda Cina dari minum teh ke kopi, bahkan banyak pengusaha muda Indonesia membuka coffee shop di Cina dengan 
menyajikan kopi-kopi dari Indonesia. Selain Cina, kopi juga banyak diekspor ke Guam, dan saat ini eksportir kopi Bali mencoba menegosiasikan agar kopi Bali bisa masuk ke pasar Dubai.

Semakin dipermudahnya aturan ekspor dari pemerintah pusat tidak serta merta membantu petani kopi Desa Catur. Akses pasar keluar negeri masih menjadi keluhan para petani disana. Hingga saat ini produk kopi arabika Kintamani yang dihasilkan lebih banyak diekspor oleh pihak ketiga. Petani seperti Pak Ketut Jati belum mengekspor produknya secara langsung. Kemudahan akses pasar yang disediakan oleh kemajuan TI belum sepenuhnya termanfaatkan oleh para petani desa Catur. Belum meratanya pendidikan hingga ke jenjang perguruan tinggi membuat para petani masih tidak terlalu aktif memanfaatkan TI.

Petani-petani kopi Desa Catur mengatakan sudah pernah ada pendampingan dan bantuan pembuatan situs web ataupun media sosial dari beberapa institusi. Namun situs web ataupun media sosial tersebut baru sampai pada tahap menampilkan profil Desa Catur ataupun pengenalan produk kopi seperti Kopi Gunung Catur. Namun yang dibutuhkan saat ini jika igin bersaing dengan eksportir lainnya adalah kemampuan technopreneurship. Kemampuan ini menggabungkan penguasaan teknologi yang baik dengan jiwa wirausaha modern yang berdaya saing global. Technopreneurship menerima investasi dan berinovasi dalam penggunaan teknologi, kemudian pengaplikasiannya dilakukan pada tenaga kerja, cara pemasaran produk serta pengaturan keuangan melalui sistem online. Belajar dari start-up coffee shop seperti Fore Coffee dan Fore Coffee yang menggunakan sistem aplikasi internet dalam pemasaran dan penjualan kopinya kepada konsumen, tentunya dapat menjadi inspirasi dalam modernisasi bentuk pemasaran produk oleh petani ataupun produsen kopi.

Namun sampai saat ini hal tersebut belum dapat terealisasi dengan baik. Pak Ketut Jati masih menganggap sulit untuk berhadapan dengan investor. Karena investor pasti menginginkan keuntungan yang besar dari penjualan kopi. Terkadang hal ini dianggap dapat menekan petani kopi. Di lain sisi kemampuan bahasa asing dan daya tawar langsung dengan buyers belum dimiliki kebanyakan petani kopi di Desa Catur: "Banyak yang datang kemari untuk tawar menawar, ada yang dari Jepang dan beberapa negara lainnya, namun yang harganya mereka inginkan masih rendah, dan tidak sesuai dengan pengeluaran kami dari memanen hingga pengolahan, makanya beberapa diantaranya kami tolak. Lemahnya penguasaan bahasa asing menjadi penghambat produsen kopi untuk berbicara langsung dengan buyers dari luar negeri untuk melakukan tawar-menawar. Sehingga para petani kopi harus berbicara melalui guide dari para buyer yang datang ke tempat pengolahan kopinya.

Anak muda lokal Desa Catur sudah saatnya melirik pertanian kopi dan saling bekerjasama dengan petani kopi yang telah senior. Para anak muda lokal tersebut dapat berlatih dan bertukar pikiran dengan petani lainnya untuk meningkatkan kemampuan, profesionalitas dan keahlian. Hal ini penting dalam membantu kelangsungan pertanian kopi di Desa Catur Kintamani. Generasi muda biasanya lebih dekat dengan penggunaan teknologi, sehingga dapat membantu mengembangkan pemasaran kopi Desa Catur yang berbasis TI.

Melihat pergeseran perdagangan kopi global yang mulai bergerak kearah penggunaan teknologi dan aplikasi, maka seharusnya pendampingan- 
pendampingan yang dilakukan oleh pemerintah untuk kopi arabika kintamani tidak hanya bantuan pembuatan situs web ataupun media sosial untuk pengenalan produk ataupun wilayah saja. Pendampingan sebaiknya difokuskan untuk penggunaan TI baik bagi petani dan pengusaha kopi Desa Catur yang lebih diarahkan pada aktivitas penjualan dan pemasaran kopi berbasis internet dan aplikasi. Berkaca pada keberhasilan gerai-gerai coffee shop yang menggunakan TI untuk mempermudah menjangkau konsumen. Tentunya pelatihan kewirausahaan modern berbasis teknologi perlu dilakukan dengan segera agar petani kopi dan pengolah kopi Gunung Catur dapat merasakan keuntungan lebih besar dari penjualan kopi mereka.

\section{KESIMPULAN DAN SARAN}

\section{Simpulan}

Merangkum kembali strategi nation branding yang diungkapkan Anholt, untuk membentuk persepsi masyarakat internasional terhadap reputasi Indonesia maka diperlukan penggalian ide-ide yang relevan terkait pengembangan produk kopi Gunung Catur. Berbagai cara dilakukan mulai dari memberikan kemudahan peraturan ekspor, mengajak BUMN-BUMN untuk membantu permodalan kepada untuk pembudidayaan kopi serta pelatihan terhadap petani. Hal tersebut dapat meningkatkan kompetensi kopi Gunung Catur dari segi kualitas. Kemudian penngunaan proses pertanian organik serta penerapan Tri Hita Karana dalam pembudidayaan kopi ini, membuat produk kopi arabika Gunung Catur diakui kontribusinya dalam menjaga lingkungan. Maka strategi nation branding yaitu kompetensi dan kontribusi telah dipenuhi oleh Kopi Gunung Catur. Namun sampai saat ini akses pasar internasional masih sulit dijangkau oleh petani dan pengolah kopi Gunung Catur karena masih belum maksimalnya strategi komunikasi. Kurangnya kemampuan berbahasa asing serta penggunaan TI yang belum maksimal melemahkan strategi komunikasi sehingga akses pasar global masih sulit untuk dijangkau secara langsung oleh petani dan pengolah kopi Gunung Catur

\section{Saran}

Melihat strategi nation branding Anholt yang ketiga, yaitu komunikasi, tampaknya teknologi menjadi alat utama untuk akses pasar. Disaat memasuki era industrialiasi 4.0 strategi komunikasi menjadi hal yang krusial. Komunikasi adalah menyampaikan pesan kepada konsumen mengenai kompetensi dan kontribusi yang dimiliki kopi Gunung Catur. Perlu pendampingan pemerintah kepada para petani dan pengolah kopi Desa Catur Kintamani untuk lebih serius dalam penguasaan TI dan mengasah jiwa enterpreneurship modern. Petani kopi Gunung Catur tidak selamanya dapat bergantung pada pemerintah hanya melalui promosi ataupun pameran. Mereka harus mandiri sesegera mungkin dengan cara mengasah kemampuan komunikasi. Maka pendampingan pemerintah untuk penguasaan komunikasi secara online dan off line perlu dilaksanakan.

\section{UCAPAN TERIMA KASIH}

Penulis mengucapkan terima kasih kepada team peneliti, para informan serta Universitas Udayana dalam membantu pelaksanaan penelitian ini 


\section{DAFTAR PUSTAKA}

Alfons, Maria. 217. Implementasi Hak Kekayaan Intelektual Dalam Negara Hukum. Jurnal Legislasi Indonesia, Vol.14, No.3 - September 2017, 357-368

Andri DP, Yustisianus, 2019. Indonesia Terpilih Sebagai Ketua Dewan Kopi Internasional. Bisnis.com

Anholt, 2003. Brand The New Justice: The Upside of Global Branding. London: Butterworth-Heinemann.

Anholt, 2010. Places: Identity, Image and Reputation. London: Palgrave: Macmillan

Buku Persyaratan Indikasi Geografis. 2007. Kopi Arabika Kintamani. Masyarakat Perlindungan Indikasi Geografis (MPIG) Kopi Arabika Kintamani

Devi, A.R dkk. 2004. Hak Kekayaan Intelektual: Siapa Bilang Dibajak Itu Enak? www.haki.lipi.go.id

Highlish Media. 2019. Menyatukan Keragaman Kopi di Indonesia Melalui Logo Generik.

Kementerian Pertanian Republik Indonesia. 2017.Pentingnya Indikasi Geografis (IG) Produk Pertanian. www.pertanian.go.id

Kristianto, Feri. 2019. Difasilitasi BI Tokyo Kopi Kintamani Jajaki Pasar Jepang. Bisnis.com

Mopangga, Herwin. 2015. Studi Kasus Pengembangan Wirausaha Berbasis Teknologi (Technopreneurship) di Provinsi Gorontalo. Trikonomika. Volume 14, No.1 Juni 2015. Hal.13-24, ISSN.2355-7737 (online)

Pitoko Ridwan Aji, 2018. Ekspor Kopi Olahan Nasional Tembus 469 Juta Dollar AS. Kompas.com

Priantara, I Dewa Gede Yoga, dkk., 2016. Analisis Nilai Tambah Pengolahan Kopi Arabika Kintamani. Jurnal Rekayasa dan Manajemen Industri. ISSN: 2503488X, Vol.4, No.4, Desember 2016 (hal, 33)

Rahayu, Sri dan Reni Kristina Arianti. 2014. Persepsi Nation Branding Sebagai Upaya Meningkatkan Kinerja Ekspor ke Jepang dan Australia. Buletin Ilmiah Litbang Perdagangan. Vol.8, No.2, Tahun 201, ISSN: 1979-9187

Sari, Ferrika, 2019. Ratusan Miliar Dana Investor Mengalir Deras ke Start-Up Kopi. Kontan.co.id

Yuliandri, Mustika Treisna. 2015. Sejarah "First, Second and Third Wave Coffee" Majalah. ottencoffe.co.id 